\title{
野生鳥獣由来食肉の安全性確保に関する研究
}

\author{
高井伸二 ${ }^{1)}$, 門平睦代 ${ }^{2)}$, 青木博史 ${ }^{3)}$, 村田浩一 ${ }^{4)}$, 前田 健 $^{5)}$, 小野文子 ${ }^{6)}$, 山本茂貴 ${ }^{7)}$ \\ 1）北里大学獣医学部 干 034-8628 青森県十和田市東 23 番町 35-1 \\ 2）帯広畜産大学 干 080-8555 帯広市稲田町西 2 線 11 番地 \\ 3）日本獣医生命科学大学 $=180-8602$ 東京都武蔵野市境南町 1-7-1 \\ 4）日本大学生物資源科学部 干 252-0880 神奈川県藤沢市亀井野 1866 \\ 5）山口大学共同獣医学部 ₹ 753-8511 山口県山口市吉田 1677-1 \\ 6）社団法人予防衛生協会試験検査室干３05-0003 茨城県つくば市桜 1-16-2 \\ 7）東海大学海洋学部 干 424-8610 静岡市清水区折戸 3-20-1
}

\section{Studies on the Safety of Meat Derived from Wild Birds and Animals in Japan}

\author{
Shinji TAKAI ${ }^{1)}$, Mutsuyo KADOHIRA², Hiroshi AOKI ${ }^{3)}$, Koichi MURATA ${ }^{4)}$, Ken MAEDA ${ }^{5)}$, \\ Fumiko $\mathrm{ONO}^{6)}$ and Shigeki YAMAMOTO ${ }^{7)}$ \\ 1) School of Veterinary Medicine, Kitasato University, Higashi 23-35-1, Towada, Aomori, 034-8628, Japan \\ 2) Obihiro University of Agriculture and Veterinary Medicine, Inada-cho, Obihiro, Hokkaido 080-8555, Japan \\ 3) School of Veterinary medicine, Nippon Veterinary and Life Science University, 1-7-1 Kyonancho, Musashino, \\ Tokyo 180-8602, Japan. \\ 4) School of Veterinary Medicine, Nihon University, 1866 Kameino, Fujisawa, Kanagawa 252-0880, Japan \\ 5) Joint Faculty of Veterinary Medicine, Yamaguchi University, 1677-1 Yoshida, Yamaguchi 753-8515, Japan.
}

6) The Corporation for Production and Research of Laboratory Primates Hachimandai 1-1, Tsukuba, Ibaraki 305-0843, Japan

7) School of Marine Science and Technology, Tokai University, 3-20-1, Orido, Shimizuku, Shimizu, Shizuoka 424-8610, Japan

\begin{abstract}
Wild animal ecologists and specialists, administrators, epidemiologists, and specialists in disease diagnosis have gathered together to form an organization for the purpose of "Ensuring the Safety of Meat Derived from Wild Birds and Animals". We have been carrying out field researches and questionnaire surveys to develop a global picture of this important topic. Thanks to an effective administrative network, we have undertaken the scientific risk assessment of the origin of wild animals on the basis of material extracted from them, research on disease-carrier situations, and the epidemiologist context. The purpose of this study is to promote adequate risk management measures by creating a "Guideline to Ensure Safety". In this symposium, we will introduce the achievements of our first-year activities by presenting the seven main purposes of our field surveys: "A Development and Administrative Study on the Surveillance Method of Wild Animals and a Research Study on the Utilization of the Capture of Wild Animals", "A Research Study on the Ecology and Capture of Deer", "Research on Ecology and the Utilization of the Capture of Wild Birds and Animals", "Research on Ecology and the Utilization of the Capture of Wild Boar", "Development of a Wild Animals' Pathogenic Diagnosis and an Antibody Assay", "Research on Food Poisoning and Foodborne Infectious Diseases", and "The Collection and Analysis of Basic Data on Meat Derived from Wild Birds and Animals".
\end{abstract}

Key words : safety, guideline, meat from wild animals and birds

Jpn. J.Zoo. Wildl. Med. 18 (3) : 83-86, 2013

\section{1. 研究目的}

我が国でも, 近年, ジビエとして野生動物肉の需要が増えて いるが，野生動物肉を安全かつ適正に利用するためのシステム は整っていない。野生動物の病原体の保有状況や野生動物肉の 利用に関する地域的な研究はこれまでにも報告されているが, 疫学者や野生動物生態学者も参加した調査, 野生動物の背景に
あるリスクやリスク評価, 有効なリスク回避措置などについて は, システマティックに検討されたことがない（図 1）。本研 究班では(1)野生動物の生態学者, 各野生動物の専門家, 行政経 験者, 疫学者, 疾病診断の専門組織などをチームとし, (2)現地 調査やアンケート調査を通じて全体像を把握する。また, (3)行 政のネットワークを利用して野生動物の採材, 病原体保有状況 の調査, 疫学的背景に基づく科学的な野生動物由来肉のリスク 


\section{野生鳥獣由来食肉の安全性確保に関する研究}

\section{・本研究課題の複雑性}

1. 野生動物の疾病サーベイランス 野生動物の污染実態の科学的な把握には，母集団の分布， 構成, 生態…などの情報が必要。野生動物生態学者と疫学 者なしには無理! 偏った情報による，風評被害を起こしや すい。

2. 野生動物の駆除と野生動物の保護・保全 野生動物の農作物被害：200 億円超, 野生動物駆除 25 万 のシカ, 10 万のイノシシ, 野生動物保全との調和。欧米 の Sustainable Hunting 理念を生かすには，環境評価，行 政者が必要!

3. 野生動物肉の安全と安定供給

と畜場に代わる簡易施設, 流通方法, 安定供給のためのネッ トワーク可食部分の衛生管理と悲可食部分の環境污染防止 （超高熱発酵法）

*上記 3 課題を解くために, 研究班を組織した。

図 1 本研究課題の複雑性

評価を行い，(4)ガイドラインを作成し，適正なリスク管理措置 を提言することを目的として研究を進める（図 2）。

\section{2. 研究方法}

本研究には 7 名の研究者が参画し, それぞれの専門分野に
関する研究計画に沿って, 以下の項目を実施している。詳細な 研究内容は, 別に研究成果報告書に記載されている。したがっ て，ここでは，主なタイトルのみをあげる。

1）(1)母集団を推定するための既存の GIS データの収集（イ ノシシとシカの分布図), (2)現場の問題点と解決策共有のため のステークホールダー会議の開催, (3)有病率推定のための「お とりサーベイランス」の実施（門平）

2) (1)野生鳥類, 特に力モ類の食肉利用について, それらを 提供している飲食店および直販業者に関する情報をインター ネットなどで収集, (2)力モ肉類の直販業者から鳥類死体を購入 し, 各種病原体検査用の試料を採取し保存, (3)狩猟者が捕獲し た力モ類の腸管および心臓を譲り受け検査試料として保存，(4) 入手した野生力モ類死体から食中毒菌の分離培養, (5)野生鳥類 を宿主とする住血原虫を指標（Bio-tracer）として鳥類生態解 明の参考とする（村田）

3）(1)食品由来の感染といわれている $\mathrm{E}$ 型肝炎ウイルスの血 清診断法の確立と PCR 法によるウイルス検出, (2)蚊媒介性の 日本脳炎ウイルスの血清診断法の確立と疫学調査。(3)豚で撲滅 されつつあるオーエスキー病ウイルスのイノシシにおける保有 状況の調査（前田）

4) (1)シ力血清を用いた豚丹毒抗体検査法の確立と血清疫学 的調査, (2)疫学的解析の指標となるシ力の生態学的特性に関す る情報の収集, (3)疫学的解析の指標となるシ力における牛ウイ

野生鳥獣由来食肉の安全性確保に関する研究

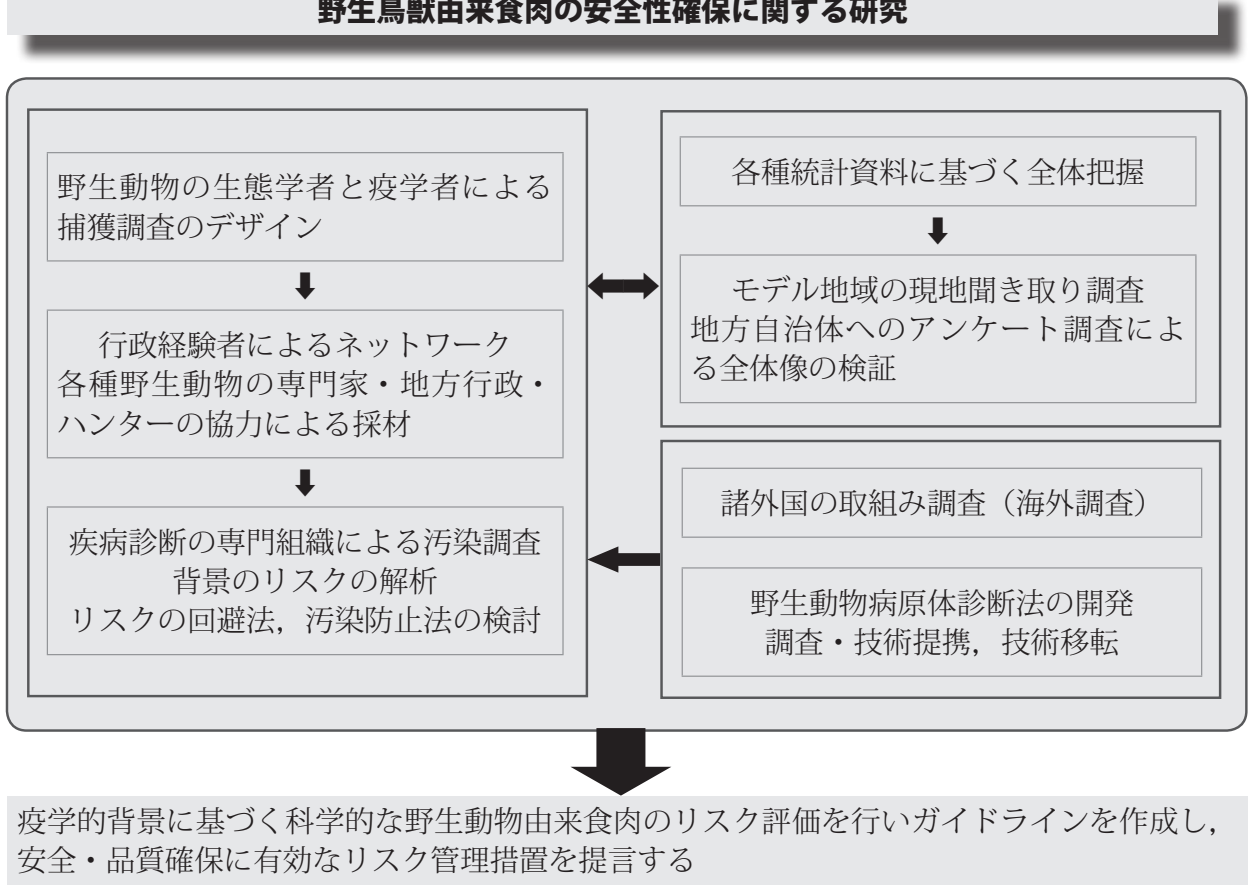

図 2 本研究の研究体制 
ルス感染症に関する情報の収集（青木）

5）(1)狩猟期および害獣駆除として捕獲し食用に供されるイ ノシシ, シカの血液, 糞便および各種臓器の材料を用いて, 血 清保存, 粪便中の腸管内病原性微生物検査（ノロウイルス, 赤 痢菌, サルモネラ, 病原性大腸菌, エルシニア, 原虫, 寄生虫), 病理組織検索を実施 (小野)

6）野生鳥獣食肉による海外および国内の食中毒の発生状況 調査をインターネットおよび文献により行った（山本）

\section{3. 研究結果の概要}

1）1の項目については, 1)イノシシとシカの国内における 分布図（GIS 情報）を収集した。(2)ステークホールダー会議を 6 月 26 日, 帯広で開催した。(3)エン゙シカとイノシシより生物 学的データと個体レベルのデータ（年齢など）の収集を開始し た。

2） 2 の項目については, (1)野生力モ類を調理し不特定多数 に提供している飲食店のインターネット情報を収集し, 料理名 や地域情報を含めてリスト化している。(2)野生力モ類を捕獲し インターネット販売している国内業者のインターネット情報を 収集し，1）と同様にリスト化している。(3)上記でリストアッ プされた業者のうち 4 県（茨城・滋賀・徳島・鹿児島）の直 販業者から力モ類死体を購入し, 病原体検査用の各種試料を採 取・保存した。(4)これまでに採取した試料のうち腸管内容を用 いて食中毒菌（サルモネラおよびカンピロバクター）の分離培 養を試みた。その結果, 茨城県および滋賀県の業者から入手し たカモ類からカンピロバクターが検出され精査中である。(5)北 海道内で狩猟者によって捕獲された力モ類の腸管を譲り受け(4) と同様の病原性細菌分離を試みたところ, カンピロバクターが 検出され精査中である。6関東圈の高標高森林地帯および沖縄 県の島嶼地域における野鳥を対象とした住血原虫および媒介昆 虫調査を実施した結果, 病原体を運搬する野鳥の生態（移動や 渡りなど）の解明に本原虫の分子系統が役立つことが明らかと なった。

3） 3 の項目では, (1)抗豚 IgG 抗体および抗シ力 IgG 抗体を 用いることによる $\mathrm{E}$ 型肝炎ウイルスの血清学的診断法の確立 に成功し，イノシシでは和歌山県の血清が全て陽性であった ことから, Cutoff 值の設定にも成功した。その結果, 山口で は $27 \%$ のイシシが陽性であることが判明した。また, 本年 山口県で発生した E 型肝炎ウイルス発症の患者の遺伝子およ びイノシシから検出されたウイルス遺伝子の相同性が高く, イ ノシシ肉を食べたことによる感染と判明した。シカでは Cutoff 值の設定中である。(2)多種類の動物に感染するといわれてい る日本脳炎ウイルスの疫学調査を可能にするために Protein A, Protein G, ProteinA/G を用いた ELISA 系の確立を試みている。
(3)豚で撲滅されつつあるオーエスキー病ウイルス（犬などが犠 牲）のイノシシにおける疫学調査を行い, 豚での撲滅に成功し た県のイノシシにまだオーエスキー病ウイルスが存在している ことが示された。

4）４の項目では, (1)菌体凝集反応を原理とした簡便な豚丹 毒抗体検査を予定しており, 収集されたシカ血清について豚丹 毒抗体検査を実施し, シ力集団に拍ける豚丹毒の污染状況を明 らかにする予定である。(2)シ力の生態に関する情報を現在, 収 集・整理している。エゾシカにおいては，(1) メスジカおよび コジカが 10 頭前後から数十頭の集団を形成して行動, (2) 越 冬地への移動（多集団が集まる広範囲な越冬地が存在），(3) 越 冬時期に集団間の行動範囲の間接的な重複がある, (4) 単独個 体の移動距離は平均約 $30 \sim 40 \mathrm{~km}$ (記録上では $100 \mathrm{~km}$ 超の 移動個体も存在）, などの生態学的知見を得ている。(3)科学論 文検索などを利用したシ力における感染症（特に牛ウイルス感 染症）の報告などを現在, 収集・整理している。これら情報は, ウイルス伝播の解析に必要となる。また, 収集されるシ力血清 について牛ウイルス性感染症の抗体検査および病原検査を実施 する予定である。

5） 5 の項目では, (1)北海道養鹿場のエゾシカ 51 頭, 栃木 のイノシシ 12 頭, 大分のシカ 1 頭について検索を行った。(2) 糞便中の病原性大腸菌はエゾシカ 50 頭およびシカ 1 頭中 25 頭から 20 種の 0 抗原に対する凝集が認められ, 12 頭で複数 の抗原に対する凝集が確認された。一方，イノシシでは抗原凝 集は 12 頭中 2 頭のみであった。その他の病原性細菌, 赤痢ア メーバはいずれのサンプルからも検出されなかった。糞便中寄 生虫卵はエゾシカ 1 頭, シ力 1 頭で検索を行い検出されなかっ たが,イノシシからは 12 頭中 11 頭から鞭虫, 回虫, 鈎虫卵 などが検出された。病理組織検索では大腿部筋肉内腫瘤が認め られ廃棄処分を行ったエゾシカは, 線虫寄生による結節と診断 された。エゾシカ, シカでは, 舌や横隔膜, 骨格筋など主に食 用に使用する筋肉での住肉包子虫寄生率が高かった。また, 肺 でも虫体の残骸とともに軽度のリンパ濾胞過形成性病変を認め た。イノシシでは, 肺での寄生虫 (肺虫様) 寄生率が高く, そ れに伴うリンパ濾胞の過形成性病変の程度が著しかったが, 主 に食用に使用する筋肉での寄生虫感染は認められなかった。

6）6の項目では, GIDEON, PubMed, CDC などを調査した 結果, ほとんどがクマ肉やイノシシ肉による旋毛虫感染に関す るアウトブレイクだった。それ以外には, 日本におけるシ力肉 およびイノシシ肉による $\mathrm{E}$ 型肝炎ウイルスによるアウトブレイ ク（2 件）, スウェーデンに提野鳥からのサルモネラ菌の 感染事例（1 件）のみであった。 


\section{4. おわりに}

実態調査を主目的として, 7つの項目について研究を展開し， 以下の成果を得た。

「野生動物サーベイランス方法の開発と行政調査および野生 動物捕獲利用に関する調査研究」では, イノシシ, 二ホンジカ の生息状況, 被害状況および肉利用に関するガイドラインに係 る資料を環境省, 農水省, 地方自治体および関係機関から収集 した。キジなどの野鳥の捕獲状況や被害状況に関する資料を収 集した。さらに，公表されている GPS データを利用し野生動 物（シカとイノシシ）の分布を可視化した。70 年代と 2000 年代の分布を比較することで, シカとイノシシの生息地域が大 幅に拡大していることが分かった。北海道と栃木県をモデル地 区として, フィールドでのネットワークを確立し, 材料の採取 および病原体診断のための体制を構築した。また, 食肉, 内臓 の処理方法に関するデータ収集を開始した。

「シ力の生態と捕獲に関する調査研究」では, シ力血清を試 料とした豚丹毒抗体検査法を検討し, 収集されたシ力血清につ いて豚丹毒に関わる血清疫学調査を実施している。シ力（主に エゾシカ）の生態学的特性に関する情報収集を行い, シ力にお ける感染症（主に牛ウイルス感染症）に関する報告など収集し ている。

「野生鳥類の生態と捕獲利用に関する調査」では, 野生力モ 類の食肉利用に関する飲食店および直販業者の情報をインター ネットなどを用いて収集した。次に, 野生力モ類の直販業者か ら鳥類死体を購入し, 各種病原体検出用の試料を採取・保存し た。入手した野生力モ類死体の腸内容から食中毒菌の分離培養 を試み, 一部からカンピロバクター様細菌が検出された。

「イノシシの生態と捕獲利用に関する調査」では, イノシシ における $\mathrm{E}$ 型肝炎, 日本脳炎ウイルスならびにオーエスキー 病ウイルス検査法を確立した。さらに, 山口県におけるイノシ シとシカの採材のためのネットワークを確立した。

「野生動物の病原体診断および抗体測定法の開発」では, 北 海道, 関東, 九州地区のシカ, イノシシのサンプルを中心に, 人に食中毒を引き起こす細菌と寄生虫の検索を微生物学的手法
と病理学的手法を用いて行った。

「食中毒, 食品由来感染症に関する調査」では, 野生鳥獣食 肉による海外抢よび国内の食中毒の発生状況調査を新聞検索, インターネットおよび文献検索により行った。

「野生鳥獣由来肉に関する基礎データ収集と解析」では, 野 生鳥獣に保菌・感染を引き起こし, さらに人に感染する人獣共 通感染症, 家畜伝染病などの疾病の一覧作成し, 現在自治体な ぞで作成されている野生鳥獣食肉の処理ガイドラインを収集・ 整理した。取りまとめた野生鳥獣食肉の処理ガイドラインを利 用しながら, 本研究の平成 23 年度の研究成果は報告書として 取りまとめた。本研究は平成 25 年度までの 3 か年となってお り, さらに研究を発展・推進し, 研究成果を取り揃えて, 「安 全性確保のためのガイドライン」を平成 25 年度末に完成させ る予定である。

\section{要 約}

「野生鳥獣由来食肉の安全性確保」のために, 野生動物の生 態学者, 各野生動物の専門家, 行政経験者, 疫学者, 疾病診断 の専門家を組織とし, 現地調査やアンケート調査を通じて「野 生鳥獣由来食肉」に関する全体像を把握し, さらに行政のネッ トワークを利用して野生動物の採材, 病原体保有状況の調査, 疫学的背景に基づく科学的な野生動物由来肉のリスク評価を行 い,「安全性確保のためのガイドライン」を作成し, 適正なリ スク管理措置を提言することを目的として, 本研究を展開して いる。実態調査を主目的として，7つの項目「野生動物サーベ イランス方法の開発と行政調査および野生動物捕獲利用に関す る調査研究 (門平睦代)」,「シ力の生態と捕獲に関する調査研 究 (青木博史) 」, 「野生鳥類の生態と捕獲利用に関する調査 (村 田浩一）」,「イノシシの生態と捕獲利用に関する調査（前田 健）」,「野生動物の病原体診断および抗体測定法の開発（小野 文子)」,「食中毒, 食品由来感染症に関する調査 (山本茂貴)」, 「野 生鳥獣由来肉に関する基礎データ収集と解析（東レリサーチ）」 について事業を展開しているので, 本シンポジウムでは, 初年 度成績を含めて概要をご紹介する。

キーワード : 安全性, ガイドライン, 野生鳥獣由来肉 